\title{
Evaluation of non-surgical periodontal treatment in patients with a past history of myocardial infarction
}

\section{Ocena niechirurgicznego leczenia periodontologicznego u pacjentów z przebytym zawałem mięśnia sercowego}

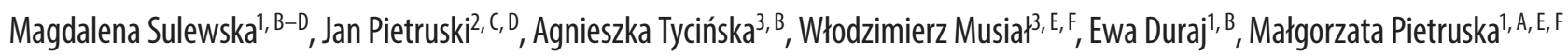 \\ 1 Departmant of Periodontal and Oral Mucosa Diseases, Medical University of Bialystok, Białystok, Poland \\ 2 Private Dental Practice, Białystok, Poland \\ ${ }^{3}$ Department of Cardiology, Medical University of Bialystok, Białystok, Poland \\ A - research concept and design; $\mathrm{B}$ - collection and/or assembly of data; $\mathrm{C}$ - data analysis and interpretation; \\ $D$ - writing the article; $E$ - critical revision of the article; $F$ - final approval of article
}

\section{Address for correspondence}

Małgorzata Pietruska

E-mail:mpietruska@wp.pl

Funding sources

none declared

Conflict of Interest

none declared

Received on 0ctober 18, 2016

Revised on November 3, 2016

Accepted on November 20, 2016

DOI

$10.17219 / \mathrm{dmp} / 67265$

Copyright

() 2017 by Wroclaw Medical University

and Polish Dental Society

This is an article distributed under the terms of the

Creative Commons Attribution Non-Commercial License

(http://creativecommons.org/licenses/by-nc-nd/4.0/)

\begin{abstract}
Background. The cohort study revealed a relationship between chronic periodontitis and the risk of developing coronary heart disease (CHD) and myocardial infarction.

Objectives. The aim of the study was to evaluate the influence of periodontal treatment on periodontal status in patients with past history of acute myocardial infarction.

Material and methods. The study comprised 45 patients with chronic periodontitis hospitalized due to acute myocardial infarction treated with coronary angioplasty. The patients were randomized to the group of non-surgical periodontal treatment (group 1; 25 individuals) or the group of periodontal prophylactics (group 2; 20 individuals). The following aspects were evaluated in clinical study: plaque index (PI), approximal plaque index (API), bleeding on probing (BOP), probing depth (PD) and clinical attachment level (CAL). The study was carried out 1-2 weeks following discharge from hospital and 6, 7 and 12 months after the initial examination.

Results. High values of PI, API and BOP were observed in both groups, which indicated poor oral hygiene and a considerable percentage of inflamed pockets. Those values significantly decreased with further control examinations, yet the obtained values were still very high. No significant changes in time were observed in PD and CAL in both groups. A significant PD reduction in the examinations performed 7 and 12 moths from the baseline was detected only in the group of younger patients who underwent non-surgical periodontal treatment.
\end{abstract}

Conclusions. The patients with past history of acute myocardial infarction show an abnormal periodontal status which does not significantly change due to constant hygienic negligence despite prophylactic-therapeutic intervention.

Key words: periodontitis, cardiovascular disease, non-surgical periodontal treatment

Słowa kluczowe: zapalenie przyzębia, choroby układu sercowo-naczyniowego, niechirurgiczne leczenie periodontologiczne 
Periodontitis is a chronic multifactor inflammatory disease which involves progressive damage to the periodontium resulting in the loss of teeth. It constitutes a serious issue in public health, the origin of social inequality, lower quality of life, reduced chewing function and esthetic defects. Moreover, it is related to increased cost of dental treatment and general health condition. ${ }^{1,2}$

Numerous research has shown a relationship between chronic periodontitis and the risk of developing cardiovascular disorders regardless of other known risk factors. $^{3-5}$ According to the analysis of epidemiology data, the incidence of coronary heart disease increases by $25-$ $72 \%$ depending on the age of the persons with periodontal disease. The risk of developing coronary heart diseases in periodontal patients increases by $25 \%$ compared with the individuals with a healthy periodontium, while in the group of men under 50 years of age this risk increases to $72 \%$. In the case of smokers with advanced periodontal disorder, the risk of developing cardiovascular disease increases 8 times., ${ }^{3,6,7}$ Meta-analysis by Bahekar et al. ${ }^{8}$ showed a correlation between the presence of deep periodontal pockets and the occurrence of cardiovascular episode. Patients with periodontal disease show 1.14-1.59 fold higher risk of developing atherosclerotic diseases compared to healthy individuals.

According to the outcomes of intervention research, effective periodontal treatment may have a positive influence on the primary and secondary prophylactics of cardiovascular diseases. D'Aiuto et al. and Matilla et al. showed that treatment of periodontitis is related to the decrease in C-reactive protein concentration (CRP), improvement in endothelial function and thus decreased risk of developing myocardial infarction. ${ }^{9-11}$ However, no intervention studies providing the data on the impact of treatment of periodontitis on the incidence of cardiovascular incidents (myocardial infarction) in a long term observation can be found. Also, no data on the effectiveness of periodontal therapy in coronary disease patients can be found.

The aim of the study was to evaluate the influence of periodontal treatment on the periodontal status in patients with a past history of acute myocardial infarction.

\section{Material and methods}

The research comprised 45 patients including 10 women and 35 men aged 35-64 years (mean 54.022 \pm 5.87) hospitalized in the Department of Cardiology of the Medical University of Białystok due to acute myocardial infarction treated with coronary angioplasty.

The inclusion criteria comprised: acute myocardial infarction, diagnosed chronic periodontitis, age under 65 years, coronary angioplasty treatment and patient's informed consent (consent for participation in the study, consent for processing personal data).
The exclusion criteria comprised: cancer, rheumatoid disease, autoimmune disease, chronic hepatic disorder, chronic renal disease in $4^{\text {th }}$ and $5^{\text {th }}$ stage, past cerebral stroke, disorders accompanying the increase in the inflammatory indexes and terminal diseases.

When discharged from the Department of Cardiology, the patients $(n=124)$ were referred to the Department of Periodontal and Oral Mucosa Diseases, Medical University of Białystok, where the first periodontal examination was carried out in order to evaluate the periodontal status and to possibly diagnose periodontitis. The examination was carried out 1-2 weeks after discharge from hospital. The following aspects were assessed: number of teeth, hygiene - plaque index (PI) according to O'Leary, approximal plaque index (API) according to Lange et al., bleeding on probing (BOP) according to Ainamo \& Bay, probing depth (PD) and clinical attachment level (CAL) at 4 measuring points. ${ }^{12-14}$ Also, the number and percentage of pockets of $P D \geq 4 \mathrm{~mm}$ were established. The study was performed with the use of a periodontal probe PCPUNC 15 (Hu-Friedy, USA).

Only the patients diagnosed with periodontitis at the initial examination were qualified to the study. Next, the patients were randomized into 2 groups and were asked to report for an appointment in 6 months. All the 124 patients having undergone initial test were diagnosed with periodontitis. Only 45 individuals reported for the examination after 6 months, although multiple phone interventions were done. Group 1 comprised 25 persons (mean age $55.95 \pm 4.37$ years), while group 2 comprised 20 persons (mean age $52.64 \pm 6.81$ years). At the second appointment (6 months after the initial examination) after a periodontal examination, the study group (group 1) was given non-surgical periodontal treatment which involved oral hygiene education and scaling with root planing (SRP). During the procedure the patients were administered antibiotics (amoxicillin $2.0 \mathrm{~g} 1 \mathrm{~h}$ before the procedure or in the case of allergy to penicillin - clindamycin $600 \mathrm{mg} 1 \mathrm{~h}$ before the procedure). Moreover, modified full mouth disinfection (FMD) was performed: double rinsing with 0.2 chlorhexidine solution for $1 \mathrm{~min}$ and 3 subgingival pocket irrigations for $10 \mathrm{~min}$ using a gel with chlorhexidine. Periodontal examination and oral hygiene education were conducted in patients from the control group (group 2). Oral cavity sanitation was also recommended to patients from both groups. Further control periodontal examinations were carried out 1 and 6 months following SRP/hygiene education appointment, which are 7 and 12 months following the initial examination.

The study was carried out in accordance with the Helsinki Declaration of 1975, as revised in 2008. All the patients gave their written informed consent for the clinical examinations. The study was approved by the Ethical Committee of the Medical University of Bialystok (R-I002/516/2011). 
Statistical analysis was performed with Statistica 10 software (StatSoft, Tulsa USA). A U Mann-Whitney test was used to carry out a non-parametric comparison between groups. For the statistical evaluation of the changes from baseline to 12 months the paired t-test was used. A p-value below 0.05 was considered statistically significant.

\section{Results}

The results indicate the poor condition of the oral cavity in patients with a past history of myocardial infarction and the diagnosis of periodontitis. According to the initial examination, the approximate number of teeth was 18.78 \pm 6.1 and decreased during a 12-month observation to $18.53 \pm 5.99$. 11 teeth were extracted including 6 in group 1 and 5 in group 2.

It was shown that oral hygiene was poor, which was confirmed by the high mean initial values of hygiene indexes: PI - 81.33\% and API - 98.46\%. Those values were slightly higher in group 1 (PI - 85.12\%, API - 99.12\%) compared to group 2 (PI - 77.83\%, API - 97.82\%). The index values significantly decreased after the second visit in both groups and remained at a similar level during the next 6 months. High hygiene index values were accompanied by high BOP values which oscillated at the level of $70 \%$ during the first two examinations. In further tests, the values of this index significantly decreased to approximately $50 \%$ regardless of the applied prophylactic-therapeutic procedure (Table 1).

According to the initial examination, 466 sites with PD $\geq 4 \mathrm{~mm}$ were observed. The total number of pockets with $\mathrm{PD} \geq 4 \mathrm{~mm}$ in the study conducted 12 months later was 444. A decrease by 31 sites with $\mathrm{PD} \geq 4 \mathrm{~mm}$ (by $4.37 \%$ ) was observed in group 1, while in group 2 the number of those sites increased by 9 (by $4.37 \%$ ) (Table 1 ).

In the group of patients who underwent SRP, a significant reduction of PD in two further control examinations was observed ( $p=0.0027)$. According to the analysis of changes in this parameter, a significant reduction of PD occurred only in people $\leq 55$ years of age. In the case of older patients, the improvement in this parameter was statistically insignificant. In the group which received only oral hygiene education, the changes in PD were statistically insignificant and were independent of the patient's age.

In both studied groups no statistically significant changes in time in CAL values were observed. Only an increase in this parameter was detected in both the study and the control group. No statistically significant differences were observed in the mean PD and CAL depending on gender. Detailed data of PD and CAL is presented in Table 2.

Table 1. Changes in the number of teeth, PD $\geq 4 \mathrm{~mm}, \mathrm{API}, \mathrm{PI}$ and $\mathrm{BOP}$ in subsequent clinical examinations

\begin{tabular}{|c|c|c|c|c|c|c|c|c|}
\hline Group & Parametr & Baseline & $\begin{array}{l}6 \text { month from } \\
\text { baseline }\end{array}$ & $\begin{array}{l}\text { PBaseline vs } \\
6 \text { month }\end{array}$ & $\begin{array}{c}7 \text { month from } \\
\text { baseline }\end{array}$ & $\begin{array}{l}\text { P6 month vs } \\
7 \text { month }\end{array}$ & $\begin{array}{l}12 \text { month } \\
\text { from baseline }\end{array}$ & $\begin{array}{l}\text { P7 month vs } \\
12 \text { month }\end{array}$ \\
\hline \multirow[t]{6}{*}{ Total } & $\begin{array}{c}\text { number } \\
\text { of teeth [n] }\end{array}$ & $845 \pm 4.61$ & $843 \pm 4.54$ & 0.39 & $841 \pm 4.49$ & 0.39 & $834 \pm 4.38$ & 0.38 \\
\hline & $\mathrm{PD} \geq 4 \mathrm{~mm}[\mathrm{n}]$ & $466 \pm 3.79$ & $472 \pm 3.72$ & 0.39 & $450 \pm 3.25$ & 0.35 & $444 \pm 3.28$ & 0.32 \\
\hline & $P D \geq 4[\%]$ & 55.14 & 55.84 & & 53.25 & & 52.54 & \\
\hline & API [\%] & $98.46 \pm 11.64$ & $88.19 \pm 12,56$ & 0.0 & $68.28 \pm 14.68$ & 0.0 & $71.894 \pm 13.42$ & 0.0 \\
\hline & $\mathrm{PI}[\%]$ & $81.33 \pm 18.23$ & $61.17 \pm 21.24$ & 0.0 & $45.28 \pm 18.21$ & 0.0 & $44.89 \pm 20.17$ & 0.0 \\
\hline & $\mathrm{BOP}[\%]$ & $73.21 \pm 18.52$ & $72.83 \pm 19.28$ & 0.39 & $52.97 \pm 16.29$ & 0.0 & $48.08 \pm 19.06$ & 0.0 \\
\hline \multirow[t]{5}{*}{ Group 1} & $\begin{array}{c}\text { number } \\
\text { of teeth [n] }\end{array}$ & $465 \pm 5.07$ & $464 \pm 4.97$ & 0.39 & $462 \pm 4.92$ & 0.39 & $459 \pm 4.77$ & 0.38 \\
\hline & $\mathrm{PD} \geq 4 \mathrm{~mm}[\mathrm{n}]$ & $246 \pm 3.47$ & $250 \pm 3.25$ & 0.38 & $227 \pm 2.56$ & 0.26 & $215 \pm 2.42$ & 0.14 \\
\hline & $\mathrm{PD} \geq 4[\%]$ & 52.79 & 53.0 & & 50.44 & & 48.42 & \\
\hline & PI [\%] & $85.12 \pm 16.41$ & $63.73 \pm 18.39$ & 0.0 & $44.94 \pm 19.12$ & 0.0 & $43.08 \pm 21.92$ & 0.0 \\
\hline & $\mathrm{BOP}[\%]$ & $74.89 \pm 18.04$ & $73.48 \pm 18.35$ & 0.38 & $51.26 \pm 19.03$ & 0.0 & $49.05 \pm 20.03$ & 0.0 \\
\hline \multirow[t]{6}{*}{ Group 2} & $\begin{array}{c}\text { number } \\
\text { of teeth [n] }\end{array}$ & $380 \pm 4.1$ & $379 \pm 3.99$ & 0.39 & $379 \pm 3.99$ & 0.39 & $375 \pm 3.85$ & 0.38 \\
\hline & $\mathrm{PD} \geq 4 \mathrm{~mm}$ & $220 \pm 4.15$ & $222 \pm 3.74$ & 0.39 & $223 \pm 2.12$ & 0.38 & $229 \pm 3.58$ & 0.36 \\
\hline & $\mathrm{PD} \geq 4[\%]$ & 47.21 & 47.0 & & 49.56 & & 51.58 & \\
\hline & API [\%] & $97.82 \pm 15,68$ & $87.48 \pm 14.73$ & 0.008 & $61.81 \pm 16.42$ & 0.0 & $67.76 \pm 16.98$ & 0.0 \\
\hline & $\mathrm{PI}[\%]$ & $77.83 \pm 20,11$ & $66.17 \pm 19.64$ & 0.029 & $46.82 \pm 18.96$ & 0.0 & $45.54 \pm 18.45$ & 0.0 \\
\hline & BOP [\%] & $70.35 \pm 19,52$ & $68.86 \pm 18.33$ & 0.74 & $53.68 \pm 19.46$ & 0.003 & $47.83 \pm 19.83$ & 0.0 \\
\hline
\end{tabular}

Number of teeth [n]; PD $\geq 4$ mm [n]; PD $\geq 4$ [\%], API [w\%], PI [w\%], BOP [w\%] - mean \pm standard deviation. 
Table 2. Mean values, standard deviation and significance level (p) of the examined variables - PD and CAL in both groups considering time factor and patients'age

\begin{tabular}{|c|c|c|c|c|c|c|c|c|}
\hline \multirow{2}{*}{ Group } & \multirow{2}{*}{ Age } & \multirow{2}{*}{ Examination } & \multicolumn{3}{|c|}{ PD } & \multicolumn{3}{|c|}{ CAL } \\
\hline & & & mean & standard deviation & $\mathrm{p}$ & mean & standard deviation & $\mathrm{p}$ \\
\hline \multirow[t]{12}{*}{ Group 1} & \multirow[t]{4}{*}{ total } & baseline & 3.59 & 0.817 & & 3.99 & 1.407 & \\
\hline & & $\begin{array}{c}6 \text { months from } \\
\text { baseline }\end{array}$ & 3.61 & 0.832 & 0.35 & 4.01 & 1.427 & 0.42 \\
\hline & & $\begin{array}{c}7 \text { months from } \\
\text { baseline }\end{array}$ & 3.37 & 0.871 & 0.005 & 3.93 & 1.469 & 0.25 \\
\hline & & $\begin{array}{l}12 \text { months } \\
\text { from baseline }\end{array}$ & 3.36 & 0.879 & 0.003 & 3.92 & 1.470 & 0.24 \\
\hline & \multirow[t]{4}{*}{$\leq 55$} & baseline & 3.66 & 0.782 & & 3.895 & 0.987 & \\
\hline & & $\begin{array}{c}6 \text { months from } \\
\text { baseline }\end{array}$ & 3.65 & 0.83 & 0.42 & 3.96 & 0.989 & 0.29 \\
\hline & & $\begin{array}{c}7 \text { months from } \\
\text { baseline }\end{array}$ & 3.37 & 0.862 & 0.009 & 3.84 & 1.048 & 0.38 \\
\hline & & $\begin{array}{l}12 \text { months } \\
\text { from baseline }\end{array}$ & 3.35 & 0.861 & 0.007 & 3.802 & 1.049 & 0.30 \\
\hline & \multirow[t]{4}{*}{$>55$} & baseline & 3.57 & 0.856 & & 4.15 & 1.771 & \\
\hline & & $\begin{array}{c}6 \text { months from } \\
\text { baseline }\end{array}$ & 3.65 & 0.849 & 0.17 & 4.12 & 1.814 & 0.39 \\
\hline & & $\begin{array}{l}7 \text { months from } \\
\text { baseline }\end{array}$ & 3.44 & 0.862 & 0.10 & 4.10 & 1.848 & 0.34 \\
\hline & & $\begin{array}{l}12 \text { months } \\
\text { from baseline }\end{array}$ & 3.43 & 0.871 & 0.05 & 4.13 & 1.842 & 0.45 \\
\hline \multirow[t]{12}{*}{ Group 2} & \multirow[t]{4}{*}{ total } & baseline & 3.61 & 0.585 & & 4.05 & 1.253 & \\
\hline & & $\begin{array}{c}6 \text { months from } \\
\text { baseline }\end{array}$ & 3.65 & 0.592 & 0.05 & 4.055 & 1.207 & 0.48 \\
\hline & & $\begin{array}{c}7 \text { months from } \\
\text { baseline }\end{array}$ & 3.60 & 0.606 & 0.47 & 4.09 & 1.264 & 0.41 \\
\hline & & $\begin{array}{l}12 \text { months } \\
\text { from baseline }\end{array}$ & 3.63 & 0.608 & 0.26 & 4.15 & 1.303 & 0.31 \\
\hline & \multirow[t]{4}{*}{$\leq 55$} & baseline & 3.4 & 0.542 & & 3.76 & 1.545 & \\
\hline & & $\begin{array}{c}6 \text { months from } \\
\text { baseline }\end{array}$ & 3.44 & 0.579 & 0.22 & 4.03 & 1.493 & 0.12 \\
\hline & & $\begin{array}{c}7 \text { months from } \\
\text { baseline }\end{array}$ & 3.39 & 0.597 & 0.42 & 4.03 & 1.547 & 0.11 \\
\hline & & $\begin{array}{l}12 \text { months } \\
\text { from baseline }\end{array}$ & 3.45 & 0.575 & 0.21 & 4.01 & 1.583 & 0.16 \\
\hline & \multirow[t]{4}{*}{$>55$} & baseline & 3.77 & 0.565 & & 4.29 & 0.883 & \\
\hline & & $\begin{array}{c}6 \text { months from } \\
\text { baseline }\end{array}$ & 3.83 & 0.524 & 0.07 & 4.07 & 0.908 & 0.23 \\
\hline & & $\begin{array}{c}7 \text { months from } \\
\text { baseline }\end{array}$ & 3.78 & 0.557 & 0.47 & 4.14 & 0.969 & 0.32 \\
\hline & & $\begin{array}{l}12 \text { months } \\
\text { from baseline }\end{array}$ & 3.78 & 0.593 & 0.45 & 4.28 & 1.002 & 0.48 \\
\hline
\end{tabular}

There were no statistically significant differences in the examined parameters with respect to the patient's gender. This may result from the participation of only 10 women in the study (22.22\% of the patients). However, it ought to be emphasized that 10 out of 13 randomized women reported for control visits.

\section{Discussion}

Our obtained results indicate poor oral hygiene in patients with a past history of myocardial infarction. This observation was confirmed by the diagnosis of periodontitis in all the 124 hospitalized patients. Another concerning fact is that those patients neglect the necessity of applying periodontal treatment. During the first appoint- 
ment each patient was educated about the relationship between periodontitis and the development of myocardial infarction. ${ }^{4,5}$ Also, the patients were informed that non-surgical periodontal treatment decreases the level of inflammatory mediators including cardiovascular diseases. ${ }^{11,15,16}$ However, the patients showed negligence of these scientific reports as only $37.5 \%$ of the qualified and randomized persons participated in the study. A similar problem was also observed by Offenbacher et al., who suggested the need to recruit patients from cardiology departments. ${ }^{17}$ The authors observed the patients' low interest in oral health in terms of the experienced myocardial infarction (death risk). Among the recruited patients, 303 volunteers participated in the first study and only 37 individuals reported for the examination after 1 year.

Dietrich et al. showed that the number of maintained teeth is a predictor of the risk of developing ischemic heart disease. ${ }^{5}$ According to these authors, such a risk is considerably higher in edentulous men compared to those with maintained dentition. Lack of maintained teeth indicates the severity of periodontal disease. According to our results, none of the patients had less than 7 teeth and their approximate number at the first visit (1 examination) was $18.78 \pm 6.1$. The initial number of teeth was 845 and decreased to 834 during a 12 -month observation. The patients agreed for extraction as the first appointment involved not only motivating and educating them in oral hygiene but they were also recommended sanitation of the oral cavity. 11 teeth were extracted, yet many more were qualified for extraction due to poor prognosis. The patients failed to report for extraction due to fear of losing teeth as well as, according to the history, due to the doctors' concerns about performing extraction in patients right after myocardial infarction. The guidelines by Dental and Cardiology Societies indicate that the majority of dental procedures are safe and do not require the need to discontinue dual antiplatelet therapy carried out in the first year after myocardial infarction. ${ }^{18}$ Patients' awareness is also reflected by the fact that $3(27.27 \%)$ out of 11 lost their teeth during a 12-month observation.

The obtained high values of oral hygiene indexes (PI - $81.33 \%$, API - 98.46\%) reflect poor oral hygiene in patients with the history of myocardial infarction. According to the medical history, the majority of patients reported to have brushed their teeth twice a day, yet as many as $35.55 \%$ (16 individuals) claimed not have brushed their teeth more than once a day. The research by de Oliveira et al. revealed a correlation between insufficient oral hygiene and the increased risk of developing cardiovascular diseases. ${ }^{19}$ The patients who never or/and rarely brushed their teeth showed an increased concentration of both CRP and fibrinogen.

In the presented protocol, the third control examination was carried out in a short, 1-month interval after the second one. The highest reduction in oral hygiene indexes in both groups was obtained at that point, which indicates the necessity of frequent check-ups and constant re-motivation of patients. This observation is concordant with the literature data which suggests that decreased bacterial potential is considerably more effective by keeping normal oral hygiene as well as intense non-surgical periodontal treatment at numerous sessions than at 1 session. ${ }^{11}$

Most of the studies carried out so far evaluated systemic and vascular consequences of the inflammatory process, evaluated the influence of periodontal treatment at indirect final points of cardiovascular diseases, and observed numerous benefits of periodontal treatment. ${ }^{17,20,21}$ What is interesting, the type of therapy showed no significant impact on the results. Importantly, patients undergoing any periodontal treatment experienced more benefits compared to patients without periodontal therapy. Beck et al. and Desvarieux et al. observed a stronger correlation between infectious measurements (in serum, crevicular fluid) and cardiovascular disease compared to the evaluation of periodontal therapy effectiveness based on clinical periodontal measurements. ${ }^{22,23}$ This is a probable cause of a small number of publications concerning the evaluation of periodontal parameters following non-surgical periodontal treatment in patients with past history of myocardial infarction.

The high initial mean values of BOP, PD and CAL obtained in own study as well as the percentage of teeth with $\mathrm{PD} \geq 4 \mathrm{~mm}$ reflect poor condition of periodontal tissues in both groups. It may be assumed that proper periodontal care and active treatment of periodontal diseases may decrease the risk of cardiovascular incidents. Therefore, proper periodontal care ought to be an integral element of medical care in patients with a past history of acute coronary syndrome and in risk groups (all patients with diagnosed ischemic disease). Every patient with a history of myocardial infarction should be referred for a dental consultation as secondary prevention. According to the available data, in the case of detecting periodontal disease in ischemic patients and/or after myocardial infarction as well as after cerebral stroke, active dental and periodontal treatment ought to be applied, which may lead to better prognosis. $^{24}$

In our research, a significant reduction of probing depth $(\mathrm{p}=0.0027)$ after non-surgical periodontal treatment (SRP) was obtained. These outcomes are confirmed in the study by Offenbacher et al., who observed a significant PD decrease in the group undergoing periodontal therapy compared to the group receiving social care only. ${ }^{17}$ Analogically to the obtained results, the authors observed a reduction in the number of pockets over 4 and $5 \mathrm{~mm}$. Our research showed a decrease in the number of 22 pockets with $P D \geq 4 \mathrm{~mm}$. In group 1 a reduction by 31 sites with high probing value was observed while in group 2 this number increased by 9 . These changes undoubtedly result from SRP therapy. According to the study by Bahekar et al., ${ }^{8}$ the reduction of the pockets with $\mathrm{PD} \geq$ $4 \mathrm{~mm}$ reduces the risk of developing coronary heart dis- 
ease by 1.14-1.59, and thus the aim of periodontal therapy ought to be elimination of the pockets over $4 \mathrm{~mm} .{ }^{8}$ In group 2, only a short, 1-month interval after control visits (between $2^{\text {nd }}$ and $3^{\text {rd }}$ appointment) led to an insignificant PD reduction, which most probably resulted from the hygiene education. According to other authors, longer intervals between the appointments resulted in the increase in PD value, which confirms the necessity of frequent and numerous control visits. ${ }^{11}$

According to the analysis of age, a significant PD improvement was observed only in younger patients randomized to group 1. Probing depth in the younger group ( $\leq 55$ years) decreased by $0.31 \mathrm{~mm}$, while in the older group ( $>55$ years) the reduction was only $0.14 \mathrm{~mm}$ and failed to reach statistical significance. The results may be concordant with the research by other authors, who noticed a strong relationship between periodontal disease in young male patients and the development of cardiovascular disorders. ${ }^{3,5,11,25,26}$ According to authors' observations, this correlation constantly decreases with age and becomes close to zero between 60-65 years of age. Dietrich et al. suggest that at a younger age periodontium is an excellent marker of periodontal disease sensitivity. ${ }^{5}$ Therefore, conducting studies on the group of male patients below 50 years of age would be of great benefit. However, our research, as well as other studies, have been limited to age groups below 65 years as cardiovascular incidents at the age below 50 are considerably rare.

The scope of inflammatory process tested at the first visit and expressed as BOP was extremely high. The value of this parameter decreased statistically significantly $(\mathrm{p}=0.0000002)$ during a 1 -year observation in both groups amounted to $49.05 \%$ and $47.83 \%$, respectively. The final outcomes are insufficient and indicate a large number of still active pockets. The largest BOP reduction (25.84\%) compared to the baseline value was observed in the group 1 , which is undoubtedly related to the mechanical removal of biofilm (SRP). Offenbacher et al. carried out a 6-month observation and obtained a statistically insignificant decrease in BOP value in the actively treated group (SRP). ${ }^{17}$

The proven relationship between development of periodontal diseases and cardiovascular disorders indicates the necessity to prevent and treat inflammation in periodontal tissues. Basic periodontal treatment is mechanotherapy, which is scaling and root planing. ${ }^{27-29}$ SRP is aimed at breaking the structure of bacterial biofilm and thus at the reduction of pathogens in periodontal pockets. Maintenance of hygiene regimen by the patient is an indispensable element of the therapy. SRP effectiveness is well documented and expressed by the reduction of probing depth, gain in clinical attachment level as well as reduced bleeding of probing. ${ }^{30-33}$ According to own study, no above mentioned benefits were observed apart from PD reduction. The failure may be explained by a single SRP procedure and lack of patients' cooperation. Chapple et al. showed that treatment effectiveness depends not only on the doctor but to a great extent on the attention of patients who should limit risk factors (smoking tobacco) and maintain good oral hygiene at all times. ${ }^{34}$ Oral hygiene education comprises demonstration of brushing method with the recommendation of suitable duration and number of the procedures during the day. The dentist expects that providing patients with information would change patients' habits and cause the improvement of oral hygiene. Unfortunately, this method has a limited impact on patients' behavior and shows short-term effects. ${ }^{35-37}$ Therefore, frequent control visits, education and re-motivation are fundamental for successful therapy. In the case of lack of everyday dental care, a single professional procedure fails to provide benefits. According to the current understanding of care of periodontal cases, patients are responsible for the course and effect of treatment. ${ }^{38}$ Patients with their needs, requirements, expectations and values are at the center. Prevention activities evolve towards more complex educational programs based on psychological methods. ${ }^{39,40}$ This means that patients play an active role in treating their disease and they partly take responsibility for treatment effectiveness. Thus, the dentist becomes the counselor who supports patients in taking the right pro-health decisions.

The obtained results are indicative of the need of nonsurgical treatment in the group of patients with a past history of myocardial infarction. Continuation of randomized research on a larger group of patients is necessary to obtain a reliable evaluation of therapy effects on the periodontal status.

\section{References}

1. Baehni P, Tonetti MS. Group 1 of the European Workshop on Periodontology: Conclusions and consensus statements on periodontal health, policy and education in Europe: A call for action-consensus view 1. Consensus report of the 1st European Workshop on Periodontal Education. Eur J Dent Educ. 2010;14(Suppl 1):2-3.

2. Eke PI, Dye BA, Wei L, Thornton-Evans GO, Genco RJ. Prevalence of periodontitis in adults in the United States: 2009 and 2010. J Dent Res. 2012;91:914-920.

3. De Stefano F, Anda RF, Kahn HS, Williamson DF, Russel CM. Dental disease and risk of coronary heart disease and mortality. BMJ. 1993;306:688-691.

4. Beck J, Garcia R, Heiss G, Vokonas PS, Offenbacher S. Periodontal disease and cardiovascular disease. J Periodontol. 1996;67:11231137.

5. Dietrich T, Jimenez M, Krall Kaye EA, Vokonas PS, Garcia RI. Agedependent associations between chronic periodontitis/edentulism and risk of coronary heart disease. Circulation 2008;117:16681674.

6. Hyman JJ, Winn DN, Reid BC. The role cigarette smoking in the association between periodontal disease and coronary heart disease. J Periodontol. 2002;73:988-994.

7. Górska R. Relationship between periodontitis and systemic disorderd. Dent Med Probl. 2009;46:379-383 [in Polish].

8. Bahekar AA, Singh S, Saha S, Molnar J, Arora R. The prevalence and incidence of coronary heart disease is significantly increased in periodontitis: A meta-analysis. Am Heart J. 2007;154:830-837.

9. D'Aiuto F, Parkar M, Andreou G, Suvan J, Brett PM, Ready D, Tonetti MS. Periodontitis and systemic inflammation: Control of the local infection is associated with a reduction in serum inflammatory markers. J Dent Res. 2004;83:156-160. 
10. Mattila K, Vesanen M, Valtonen V, Nieminen M, Palosuo T, Rasi V Asikainen S. Effect of treating periodontitis on C-reactive protein levels: A pilot study. BMC Infect Dis. 2002;10:2-30.

11. Tonetti MS, Van Dyke TE. Periodontitis and atherosclerotic cardiovascular disease: Consensus report of the Joint EFP/AAP Workshop on Periodontitis and Systemic Diseases. J Periodontol. 2013;84 (Suppl 4):24-29.

12. O'Leary TJ, Drake RB, Naylor JE. The plaque control record. J Periodontol. 1972;43:38.

13. Lange DE, Plegmann HC, Eenboom A, Promsberger A. Klinische Bewertungsverfahren zur Objektivierung der Mundhygiene. Dtsch Zahnärztl Z. 1977;32:44-47.

14. Ainamo J, Bay I: Problems and proposals for recording gingivitis and plaque. Int Dent J. 1975;25:229-235.

15. Rodrigues DC, Taba MJ, Novaes AB, Souza SL, Grisi MF. Effect of non-surgical periodontal therapy on glycemic control in patients with type 2 diabetes mellitus. J Periodontol. 2003;74:1361-1367.

16. Taylor GW, Burt BA, Becker MP, et al. Non-insulin dependent diabetes mellitus and alveolar bone loss progression over 2 years. J Periodontol. 1998;69:76-83.

17. Offenbacher S, Beck JD, Moss K, et al. Results from the Periodontitis and Vascular Events (PAVE) study: A pilot multicentered, randomized, controlled trial to study effects of periodontal therapy in a secondary prevention model of cardiovascular disease. J Periodontol. 2009;80:190-201.

18. Pruszczyk P, Ciurzyński M, Opolski G, et al. Common dental-cardio position for dealing anticoagulation in patients undergoing dental procedures. Kardiol Pol. 2016;74:87-98.

19. De Oliveira C, Watt R, Hammer M. Tooth brushing, inflammation, and risk of cardiovascular disease: Results from Scottish Health Survey. BMJ. 2010;340:2451

20. Tonetti MS, D'Aiuto F, Nibali $L$, et al. Treatment of periodontitis and endothelial function. N Engl J Med. 2007;356:911-920.

21. Piconi S, Trabattoni D, Luraghi C, et al. Treatment of periodontal disease results in improvements in endothelial dysfunction and reduction of the carotid intima-media thickness. FASEB J. 2009;23:1196-1204.

22. Beck JD, Eke P, Lin D. Associations between IgG antibody to ora organisms and carotid intima-medial thickness in communitydwelling adults. Atheroscler. 2005;183:342-348.

23. Desvarieux M, Demmer RT, Rundek T. Relationship between periodontal disease, tooth loss, and carotid artery plaque. The oral infections and vascular disease epidemiology study (INVEST). Stroke 2003;34:2120-2125.

24. Górska R. Sprawozdanie z niezależnego panelu ekspertów na temat związku chorób przyzębia z chorobami ogólnoustrojowymi. Kardiol Pol. 2009;67:708-710 [in Polish].
25. Geismar K, Stoltze K, Sigurd B, Gyntelberg F, Holmstrup P. Periodontal disease and coronary heart disease. J Periodontol. 2006;77:15471554.

26. D'Aiuto F, Orlandi M, Gunsolley JC. Evidence that periodontal treatment improves biomarkers and ACVD outcomes. J Clin Periodontol. 2013;40(Suppl 14):85-105.

27. Sanz I, Alonso B, Carasol M, Herrera D, Sanz M. Nonsurgical treatment of periodontitis. J Evid Base Dent Pract. 2012;1:76-86.

28. Meissner G, Kocher T. Calculus-detection technologies and their clinical application. Periodontol. 2000;2011:55, 189-204.

29. Jepsen S, Deschner J, Braun A, Schwarz F, Eberhard J. Calculus removal and the prevention of its formation. Periodontol. 2000;2011, 55:167-188.

30. Suvan JE. Effectiveness of mechanical nonsurgical pocket therapy. Periodontol. 2000;2005, 37:48-71.

31. Cobb CM. Non-surgical pocket therapy: Mechanical. Ann Periodontol. 1996;1:443-490.

32. Van Der Weijden GA, Timmerman MF. A systematic review on the clinical efficacy of subgingival debridement in the treatment of chronic periodontitis. J Clin Periodontol. 2002;29(Suppl 3):55-71.

33. Adriaens PA, Adriaens LM. Effects of nonsurgical periodontal therapy on hard and soft tissues. Periodontol. 2000;2004, 36:121-145.

34. Chapple IL, Van Der Weijden F, Doerfer C, et al. Primary prevention of periodontitis: Managing gingivitis. J Clin Periodontol. 2015;42 (Suppl 16):71-76.

35. Johansson LA, Oster B, Hamp SE. Evaluation of cause related periodontal therapy and compliance with maintenance care recommendations. J Clin Periodontol. 1984;11:689-699.

36. Kay EJ, Locker D. Is dental health education effective? A systematic review of current evidence. Comm Dent Oral Epidemiol. 1996;24:231-235.

37. Schüz B, Sniehotta FF, Wiedemann A, Seemann R. Adherence to a daily flossing regimen in university students: Effects of planning when, where, how and what to do in the face of barriers. J Clin Periodontol. 2006;33:612- 619.

38. Miller WR, Rollnick S. Motivational interviewing: Preparing people for chance. $2^{\text {nd }}$ ed. New York, Guilford, 2002.

39. Clarkson JE, Young L, Ramsay CR, Bonner BC, Bonetti D. How to influence patient oral hygiene behavior effectively. J Dent Res. 2009;88:933-937.

40. Jönsson B, Ohrn K, Oscarson N, Lindberg P. The effectiveness of an individually tailored oral health educational program on oral hygiene behavior in patients with periodontal disease: A blinded randomized-controlled clinical trial (one-year follow-up). J Clin Periodontol. 2009;36:1025-1034. 